\title{
Motor re-training and immobilisation in the treatment of writer's cramp: a clinical and fMRI study
} Re-trening motoryczny i unieruchomienie w terapii kurczu pisarskiego: ocena kliniczna i fMRI

\author{
1 Department of Extrapyramidal Diseases, Medical University of Lodz, Łódź, Poland \\ 2 Department of Radiology, Medical University of Lodz, Łódź, Poland \\ ${ }^{3}$ Department of Medical Rehabilitation, Medical University of Lodz, Łódź, Poland \\ ${ }^{4}$ Department of Radiology and Diagnostic Imaging, Barlicki University Hospital, Medical University of Lodz, Łódź, Poland \\ Correspondence: Agata Gajos MD, PhD, Department of Extrapyramidal Diseases, Medical University of Lodz, Pomorska Str. 251, 92-213 Łódź, Poland, e-mail: agata.gajos@umed.lodz.pl \\ Drn. med. Agata Gajos, Klinika Chorób Układu Pozapiramidowego, Uniwersytet Medyczny w łodzi, Oddział Dzienny, Poradnia Neurologiczna, Centralny Szpital Kliniczny w Łodzi, ul. Pomorska 251, 92-213 Łódź, \\ tel.: +4842 2725744/45, e-mail:agata.gajos@umed.lodz.pl
}

\begin{abstract}
Objectives: The aim of the paper was to: (1) evaluate the effectiveness of the physiotherapeutic program in writer's cramp, (2) compare the brain activity while writing in patients with writer's cramp and in healthy controls, (3) compare the brain activity of subjects with writer's cramp before and after the physiotherapy. Material and methods: Nine patients with diagnosed writer's cramp and nine age-matched healthy controls were studied. The functional magnetic resonance imaging while writing was performed in the writer's cramp subjects and in the controls. The patients with writer's cramp participated in a 3-week therapeutic program of individualised exercises in combination with the immobilisation of the affected limb. The functional magnetic resonance imaging was repeated after completing the therapeutic program. Results: Only the results of the coil drawing test significantly improved after completing the therapeutic program. All other clinical tests did not reveal any significant changes after the therapy. Activation of primary motor cortex, premotor cortex and primary sensory cortex was observed while writing in the subjects with writer's cramp and in the controls. Brain activation in clusters located in the areas BA4, BA7, BA18 and BA37 was more pronounced in the writer's cramp group. Individual analysis revealed a significantly increased activation of the cerebellum in the writer's cramp patients and it decreased after physiotherapy. Conclusion: In the writer's cramp subjects, functional magnetic resonance imaging revealed increased - when compared to the controls - activity of several brain structures while writing. This activity was modified by individualised physiotherapeutic program.
\end{abstract}

Keywords: writer's cramp, motor re-training, immobilisation, functional MRI

Streszczenie Celami pracy były: (1) ocena skuteczności programu fizjoterapeutycznego w kurczu pisarskim, (2) porównanie aktywności mózgu podczas pisania u pacjentów z kurczem pisarskim i osób zdrowych, (3) porównanie aktywności mózgu podczas pisania u pacjentów z kurczem pisarskim przed fizjoterapią i po jej przeprowadzeniu. Materiał i metody: Badaniem objęto grupę 9 pacjentów z kurczem pisarskim i 9 zdrowych ochotników. Funkcjonalne obrazowanie metodą rezonansu magnetycznego wykonano podczas pisania w obu grupach. Pacjenci z kurczem pisarskim uczestniczyli w 3-tygodniowym programie terapeutycznym obejmującym zindywidualizowane ćwiczenia w połączeniu z unieruchomieniem zajętej kończyny. W grupie z kurczem pisarskim badanie funkcjonalnym rezonansem magnetycznym przeprowadzono ponownie po zakończeniu programu terapeutycznego. Wyniki: Tylko test rysowania spirali wykazał statystycznie istotną poprawę po zakończeniu programu terapeutycznego. Wszystkie inne testy kliniczne nie ujawniły znamiennych różnic. Zarówno u pacjentów z kurczem pisarskim, jak i u osób zdrowych stwierdzono podczas pisania aktywację pierwotnej kory ruchowej, przedruchowej i pierwotnej czuciowej. Aktywacja w polach BA4, BA7, BA18 i BA37 była silnej wyrażona w grupie z kurczem pisarskim. W tej grupie stwierdzono również istotnie większą aktywację móżdżku, która zmniejszyła się po terapii. 


\begin{abstract}
Wniosek: U pacjentów z kurczem pisarskim funkcjonalne obrazowanie metodą rezonansu magnetycznego wykazało zwiększoną - w porównaniu z osobami zdrowymi - aktywację szeregu ośrodków w mózgu. Aktywność ta ulegała modyfikacji w następstwie zindywidualizowanego programu fizjoterapeutycznego.
\end{abstract}

Słowa kluczowe: kurcz pisarski, re-trening motoryczny, unieruchomienie, funkcjonalne obrazowanie metodą rezonansu magnetycznego

\section{INTRODUCTION}

$\mathrm{W}$ riter's cramp (WC) is classified as an isolated, task-specific hand dystonia (Albanese et al., 2013; Pirio Richardson et al., 2017). WC is characterised by involuntary spasms of the hand, forearm and upper arm muscles, triggered selectively by writing. The aetiology of WC remains still unknown, but recent evidences suggest the involvement of both genetic and environmental factors. It is believed that task-specific dystonias are a result of long-term, systematic repetition of a specific activity in genetically predisposed individuals. A genomewide analysis revealed an association with the arylsulfatase G gene in WC and in musician's hand dystonia, but no specific causative mutation within this gene has been identified (Lohmann et al., 2014; Nibbeling et al., 2015).

The hypothesis of maladaptive neuroplasticity related to excessive, repetitive exercise of a learned activity (Altenmüller et al., 2012; Hubsch et al., 2013) has been proposed. The main risk factor for this form of dystonia is the number of hours spent repeating a specific task (Rozanski et al., 2015). Both the abnormal cortical inhibition and altered neuronal plasticity were found in subjects with task specific hand dystonia (Bäumer et al., 2007; Elbert et al., 1998; Nelson et al., 2009; Pirio Richardson et al., 2014; Quartarone et al., 2003; Siebner and Rothwell, 2003).

All proposed WC treatments are of very limited effectiveness and the gold standard is still needed (Goldman, 2015). It has been suggested that physiotherapy may be used to produce a cortical reorganisation. Physiotherapeutic programs are focused on sensory retuning, because there is growing evidence showing the role of the dysfunction at different levels of the somatosensory system (Byl and McKenzie, 2000; Cogiamanian et al., 2009). According to a systematic review (Enke and Poskey, 2018) of the results of several different re-education programs (constraint-induced therapy plus motor control retraining, sensory motor retuning, learning-based sensorimotor training, slow-down exercise), there is moderate evidence to support the effectiveness of these interventions in musicians' dystonia.

\section{MATERIAL AND METHODS}

\section{Material}

Nine right-handed patients ( 8 women and 1 man, mean age $46.8 \pm 5.0$ ) with the diagnosis of WC and 9 sex- and agematched (44.3 \pm 10.6 years) healthy controls were studied.
The mean disease duration was $8.4 \pm 6.6$ years. In 4 patients, simple WC was diagnosed while the other 5 subjects suffered from a complex form of the disorder.

The study was approved by the ethical committee at the Medical University of Lodz and-written informed consent was obtained from all the patients enrolled.

\section{Clinical evaluation}

Initially, all patients underwent a very careful evaluation of the dystonic movements that appeared while writing. The aim of this evaluation was to have the most complete characteristics of involuntary movements, including the distinction between the primary dystonic and the compensatory finger movements. Among other things, patients were asked to write without using the index finger, and then without the finger III and IV. The presence of flexion or extension of the unused finger, as well as wrist movements, were subject to evaluation while writing. After identifying the primary dystonic movements of the fingers and wrist, an individualised thermoplastic splint was prepared for each patient. The splints were designed to prevent incorrect hand positioning resulting from dystonic flexion or extension movements.

All patients completed a three-week physiotherapy program during which one therapeutic session took place every working day. The first part of each session consisted of performing routine daily activities for one hour, with the splint on the dystonic limb. The second part of the session was composed of a series of the following exercises performed with fingers immobilised with the splint:

- flexion and extension of every finger in proximal interphalangeal (PIP) joints for 2 minutes;

- two minutes of finger tapping with the wrist immobilised with the splint;

- movements imitating drawing circles, clockwise and anticlockwise, for 2 minutes with each finger tip;

- movements imitating writing single letters $m$ and $p$ for 2 minutes with each finger tip;

- movements imitating writing two-letter $m m$ and $p p$ sequences for 2 minutes with each finger tip.

The clinical evaluation included the following tests performed before starting and after completing the physiotherapeutic program:

- Burke-Marsden-Fahn Dystonia Scale (BMFDS) (Burke et al., 1985),

- Arm Dystonia Disability Scale (ADDS) (Jabusch et al., 2004); 
- the number of letters $p$ and number of letters $m$ written separately in 30 seconds;

- the number of errors made when writing connected letters $e$ and $s$ within 1 minute; the error was defined as a presence of space between the letters or a letter written illegibly;

- the coil drawing test; occurrence of coil line curves at an angle or of an interruption in the coil was considered an error;

- Visual Analogue Scale (VAS); the subjective evaluation of the severity of hand dystonia.

In all the subjects enrolled into the study, structural and functional magnetic resonance imaging (fMRI) was performed using the standard head coil in the $1.5 \mathrm{~T}$ MRI scanner (Siemens, Magnetom Vision+). Based on the blood oxygenation level dependent (BOLD) effect, the fMRI examination was conducted before and after completing the physiotherapeutic program. A series of localiser images was obtained in the axial, coronal and sagittal planes. Those 21 slices were then positioned in a transverse plane, parallel to the anterior and posterior commissure (AC/PC) axis with the direction from the base of the brain to the vertex. The technical parameters for the echo-planar images (EPI) included the following: TR - $1.68 \mathrm{~s}$; TE - $64 \mathrm{~ms}$; flip angle $-90^{\circ}$; thickness $-3 \mathrm{~mm}$; matrix $-64^{\star} 128$, FOV -210 . Immediately after the functional data acquisition had been performed, anatomical images were obtained with the spinecho (SE) T1 technique using: TR - $588 \mathrm{~ms}$; TE - $15 \mathrm{~ms}$; flip angle $-90^{\circ}$, thickness $-3 \mathrm{~mm}$; matrix $-128^{\star} 128$, FOV 210. Scans in T1 SE and EPI techniques were obtained exactly in the same plane orientation.

EPI technique was used while carrying out a specific task writing the word "Warszawa" (the Polish name of "Warsaw") with a pencil. The paradigm was presented in a block design manner. Total imaging time for fMRI was approximately 15 minutes.

Before the procedure was conducted for the first time, the subjects were trained to perform the task. Each block lasted 30 seconds. The periods consisted of two blocks (rest and activation) and were repeated 3 times, each procedure beginning with a period of rest.

The fMRI data were analysed with use of the Statistical Parametric Map (SPM) 99 software. Prior to the statistical analysis, the functional images were smoothed with a 5-pixel-wide kernel filter to increase the statistical power. Voxels were considered as significant when $p<0.0001$ (the Student's $t$-test). Statistically significant pixel locations, colour-coded, were superimposed on T1-weighted anatomical images obtained in the same anatomical location. Each patient's data were obtained from a volume of interest determined by manual marking of its borders. The volume of interest (VOI) contained activated clusters within the nearest local maximum in the cerebellum. The comparison between the groups was performed with the Statgraphics Plus.

\section{RESULTS}

\section{Clinical tests}

The numbers of errors made during the coil drawing test was significantly smaller after the completion of the therapeutic program. All the other clinical tests did not reveal any significant changes after the therapy. The results of the clinical evaluation of dystonia are presented in Tab. 1.

\section{fMRI and SPM}

Compared to the control subjects, significantly increased activations of primary motor cortex (Brodmann area 4), secondary sensorimotor cortex (BA7), secondary visual cortex (BA18) and cortex involved in lexico-semantic associations (BA37) were observed while writing in the WC subjects. In the WC patients, this activity was diminished after the physiotherapy.

Individual analysis revealed significantly increased activation of cerebellum while writing in the WC patients when compared to the controls. After completing the

\begin{tabular}{|c|c|c|c|c|c|c|c|c|}
\hline Test & $\begin{array}{l}\text { Burke- } \\
\text { Marsden- } \\
\text { Fahn Dystonia } \\
\text { Scale }\end{array}$ & $\begin{array}{l}\text { Arm Dystonia } \\
\text { Disability } \\
\text { Scale }\end{array}$ & $\begin{array}{l}\text { Coil drawing } \\
\text { test }\end{array}$ & $\begin{array}{c}\text { Number } \\
\text { of letter } p \\
\text { written in } \\
30 \text { seconds }\end{array}$ & $\begin{array}{c}\text { Number } \\
\text { of letter } m \\
\text { written in } \\
30 \text { seconds }\end{array}$ & $\begin{array}{l}\text { Number of } \\
\text { errors made } \\
\text { when writing } \\
\text { connected } \\
\text { letterse }\end{array}$ & $\begin{array}{c}\text { Number of } \\
\text { errors made } \\
\text { when writing } \\
\text { connected } \\
\text { letterss }\end{array}$ & $\begin{array}{c}\text { Visual } \\
\text { Analogue } \\
\text { Scale }\end{array}$ \\
\hline $\begin{array}{l}\text { Results before } \\
\text { treatment }\end{array}$ & $4.6 \pm 0.5$ & $2.6 \pm 0.5$ & $25.8 \pm 10.8$ & $27.2 \pm 5.7$ & $20.6 \pm 2.8$ & $34.0 \pm 15.3$ & $25.8 \pm 25.4$ & $6.7 \pm 1.6$ \\
\hline $\begin{array}{l}\text { Results after } \\
\text { treatment }\end{array}$ & $4.4 \pm 0.5$ & $2.4 \pm 0.5$ & $14.6 \pm 9.4$ & $31.2 \pm 6.5$ & $22.8 \pm 5.0$ & $26.2 \pm 14.2$ & $14.6 \pm 12.5$ & $5.4 \pm 1.3$ \\
\hline$p$-value* & ns & ns & $p<0.05$ & ns & ns & ns & ns & ns \\
\hline
\end{tabular}




\begin{tabular}{|c|c|c|c|}
\hline \multicolumn{3}{|c|}{ Group } & \multirow{2}{*}{-value* } \\
\cline { 1 - 2 } (1) Controls & $\begin{array}{c}\text { (2) WC subjects } \\
\text { before therapy }\end{array}$ & $\begin{array}{c}\text { (3) WC subjects } \\
\text { after therapy }\end{array}$ & \\
\hline $\begin{array}{c}6.0 \pm 18.1 \\
(0-54)\end{array}$ & $\begin{array}{c}34.1 \pm 30.5 \\
(0-95)\end{array}$ & $\begin{array}{c}13.8 \pm 13.3 \\
(0-34)\end{array}$ & $\begin{array}{c}(1) \text { vs. (2) } \\
(2) \text { vs. (3) } \\
p=0.02993\end{array}$ \\
* Mann-Whitney test. & & \\
\hline
\end{tabular}

Tab. 2. Number of activated clusters in the cerebellum $(\mathrm{n}=9)$

A.
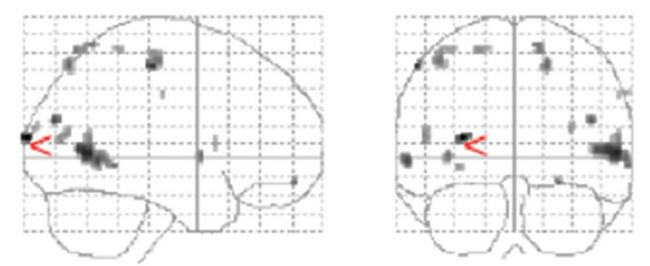

\section{$\operatorname{SPM}\left\{\mathrm{T}_{1188}\right\}$}

physiotherapeutic program, significant reduction of cerebellum activity was determined (Tab. 2).

\section{DISCUSSION}

Both pharmacological and non-pharmacological therapies are proposed for WC. The latter include, among others, physical and occupational therapy, limb immobilisation, sensory retraining and the use of various adaptive devices (Goldman, 2015). There is no evidence for a significant advantage of one of these methods over the others, and it has been suggested that combining two methods may be more effective than one used alone (Cogiamanian et al., 2009).

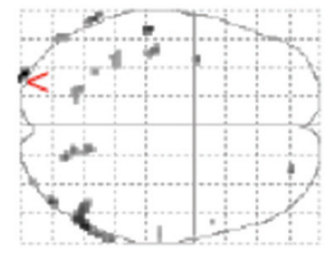

Height threshold: $\mathrm{T}=4.82, p=0.000(0.050)$

Extent threshold: $\mathrm{k}=4$ voxels, $p=0.175(0.009)$

Expected voxels per cluster, $\langle\mathrm{k}\rangle=2.315$

Expected number of clusters, $<c>=0.01$

Expected false discovery rate, $<=0.00$
B.

\begin{tabular}{|rrr|c|}
\hline \multicolumn{2}{|c|}{$\mathbf{x , y} \mathbf{z}\{\mathbf{m m}\}$} & Brodmann's area \\
\hline-30 & -98 & 12 & BA18 \\
\hline 58 & -64 & 4 & BA37 \\
\hline-62 & -58 & -2 & BA37 \\
\hline 18 & -74 & 54 & BA7 \\
\hline-44 & -22 & 56 & BA4 \\
\hline 14 & -70 & 64 & BA37 \\
\hline 14 & -60 & 66 & BA7 \\
\hline-22 & -66 & 64 & BA7 \\
\hline
\end{tabular}

Degrees of freedom $=[1.0,1188.0]$

Smoothness FWHM $=7.78 .59 .2\{\mathrm{~mm}\}=3.9 .4 .2 .4 .6$ \{voxels\}

Search vol: $1135176 \mathrm{cmm}$; 141897 voxels; 1727.4 resels

Voxel size: $[2.0 .2 .0 .2 .0] \mathrm{mm}$ (1 resel $=75.56$ voxels)

Fig. 1. Activated centres in patients with writers' cramp vs. healthy controls. Results of fMRI examination in SPM v. 99 analysis. A. Glass brain illustration. B. Coordinates of obtained activities and assignment to the Brodmann areas

A.
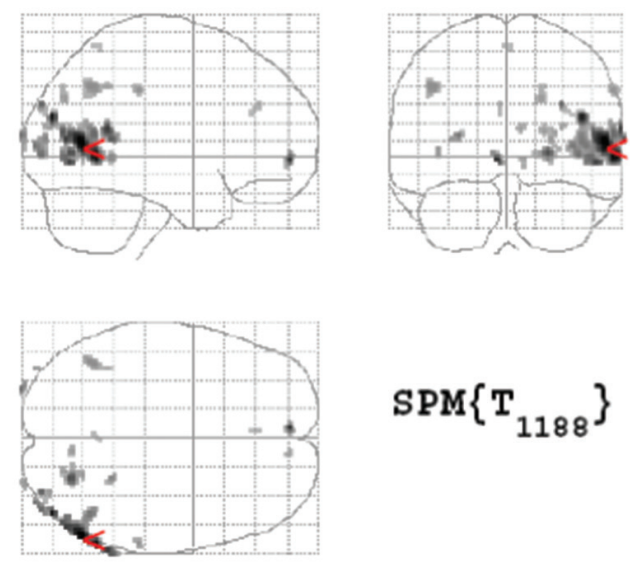

$\operatorname{SPM}\left\{\mathrm{T}_{1188}\right\}$
B.

\begin{tabular}{|rrr|c|}
\hline \multicolumn{2}{|c|}{$\mathbf{x}, \mathbf{y}, \mathbf{z}\{\mathbf{m m}\}$} & Brodmann's area \\
\hline 56 & -66 & 8 & BA37 \\
\hline 66 & -50 & 164 & BA22 \\
\hline 16 & -70 & 2 & BA18 \\
\hline 42 & -88 & 0 & BA18 \\
\hline 44 & -86 & 10 & BA18 \\
\hline 42 & -58 & 40 & BA40 \\
\hline
\end{tabular}

Degrees of freedom $=[1.0,1188.0]$

Smoothness FWHM $=7.78 .59 .2\{\mathrm{~mm}\}=3.9 .4 .2 .4 .6$ \{voxels\}

Search vol: $1135176 \mathrm{cmm} ; 141897$ voxels; 1727.4 resels

Voxel size: $[2.0 .2 .0 .2 .0] \mathrm{mm}$ (1 resel $=75.56$ voxels)

Height threshold: $\mathrm{T}=4.82, p=0.000(0.050)$

Extent threshold: $\mathrm{k}=4$ voxels, $p=0.175(0.009)$

Expected voxels per cluster, $\langle\mathrm{k}\rangle=2.315$

Expected number of clusters, $\langle\mathrm{c}>=0.01$

Expected false discovery rate, $<=0.00$

Fig. 2. Activated centers in patients with writers' cramp before vs. after therapy. Results of fMRI examination in SPM v. 99 analysis. A. Glass brain illustration. B. Coordinates of obtained activities and assignment to the Brodmann areas 
Learning to read Braille, used as a form of sensory training, reduced the severity of hand dystonia after daily sessions in the period of 8 weeks and further improvement was observed after continuing the therapy for a year (Zeuner and Hallett, 2003; Zeuner et al., 2002). In other group of subjects with occupational hand dystonia, the retraining was effective to the extent that patients could return to work (Byl and McKenzie, 2000). It was demonstrated that, in order to be clinically effective, retraining did not need to specifically focus on the task affected by dystonia (Zeuner et al., 2008).

Long-term immobilisation alone had very limited effectiveness and its use was associated with numerous complications (Pesenti et al., 2004; Priori et al., 2001).

Transcranial direct simulation was shown to enhance the response to rehabilitation in patients with musician's dystonia (Furuya et al., 2014). Furthermore, anodal transcranial direct current stimulation targeting the cerebellum produced improvement of handwriting in patients with WC (Bradnam et al., 2015).

In our study, we combined motor retraining with selective, individualised hand immobilisation. Unfortunately, we were unable to demonstrate any clinical improvement produced by this intervention. One of the possible explanations of these results could be that the physiotherapy was not carried out for a longer period of time.

Regardless of the lack of clinical effects, we were able to demonstrate that the retraining program produced modification of brain activity demonstrated by fMRI. As compared to the controls, in our WC patients the initial evaluation revealed increased brain activity while writing - in the cerebellum, contralateral primary motor cortex, contralateral tertiary somatosensory cortex, contralateral area responsible for apraxia and the contralateral area of visual processing and procedural memory.

Increased brain activity of the cerebellum and somatosensory motor cortex during writing had been reported previously in WC subjects. The fMRI study (Preibisch et al., 2001) revealed an abnormal activity in the ipsilateral cerebellum, contralateral premotor cortex, sensorimotor cortex and thalamus. Others (Hu et al., 2006) also showed a significant activation of the ipsilateral cerebellum and contralateral primary sensorimotor cortex, supplementary motor cortex, premotor cortex and basal ganglia (putamen).

Resting-state fMRI with independent component analysis studies suggested altered connectivity between the cerebellar and basal ganglia network in WC (Mantel et al., 2017). Also, recently published studies (Jhunjhunwala et al., 2017) on eye-hand coordination and the evaluation of eye movements also suggest the involvement of the cerebellum in the pathogenesis of WC.

Moreover, in WC patients, during individual finger control and coupled tasks significant differences in activation and connectivity were observed compared to the controls (Moore et al., 2012). The increased connectivity of senso- that both the affected and unaffected areas of the striatum are involved in compensatory mechanisms (Moore et al., 2012). The results of studies in patients with taskspecific dystonia suggested that finger representations in the primary somatosensory cortex are probably "closer to each other" than in healthy subjects (Nelson et al., 2009). Recently, using dynamic causal modeling for fMRI, Rothkirch et al. (2018) were able to demonstrate malfunction in the effective connectivity intracortically and in the corticobasal ganglia circuitry in WC, as well as abnormal reciprocal excitatory connectivity in the cortico-cerebellar circuitry.

Based on the current state of knowledge, it cannot be determined whether the observed changes in the brain activity are directly related to the mechanism responsible for the WC, and to what extent they reflect compensatory mechanisms. Little is also known about the effects of physiotherapy on the brain activity abnormalities related to WC. Perhaps more complex interpretation of the influence of physiotherapy on the brain activity shown by fMRI will be possible in the case of studies demonstrating also a positive clinical effect of therapeutic intervention.

\section{Conflict of interest}

The authors do not report any financial or personal connections with other persons or organisations which might negatively affect the content of this publication and/or claim authorship rights to this publication.

\section{References}

Albanese A, Bhatia K, Bressman SB et al.: Phenomenology and classification of dystonia: a consensus update. Mov Disord 2013; 28 : 863-873.

Altenmüller E, Baur V, Hofmann A et al.: Musician's cramp as manifestation of maladaptive brain plasticity: arguments from instrumental differences. Ann N Y Acad Sci 2012; 1252: 259-265.

Bäumer T, Demiralay C, Hidding U et al.: Abnormal plasticity of the sensorimotor cortex to slow repetitive transcranial magnetic stimulation in patients with writer's cramp. Mov Disord 2007; 22: 81-90.

Bradnam LV, Graetz LJ, McDonnell MN et al.: Anodal transcranial direct current stimulation to the cerebellum improves handwriting and cyclic drawing kinematics in focal hand dystonia. Front Hum Neurosci 2015; 9: 286.

Burke RE, Fahn S, Marsden CD et al.: Validity and reliability of a rating scale for the primary torsion dystonias. Neurology 1985; 35 : 73-77.

Byl NN, McKenzie A: Treatment effectiveness for patients with a history of repetitive hand use and focal hand dystonia: a planned, prospective follow-up study. J Hand Ther 2000; 13: 289-301.

Cogiamanian F, Barbieri S, Priori A: Novel nonpharmacologic perspectives for the treatment of task-specific focal hand dystonia. J Hand Ther 2009; 22: 156-161.

Elbert T, Candia V, Altenmüller E et al.: Alteration of digital representations in somatosensory cortex in focal hand dystonia. Neuroreport 1998; 9: 3571-3575.

Enke AM, Poskey GA: Neuromuscular re-education programs for musicians with focal hand dystonia: a systematic review. Med Probl Perform Art 2018; 33: 137-145.

Furuya S, Nitsche MA, Paulus W et al.: Surmounting retraining limits in musicians' dystonia by transcranial stimulation. Ann Neurol 2014; 75: 700-707. 
Goldman JG: Writer's cramp. Toxicon 2015; 107: 98-104.

Hu XY, Wang L, Liu $\mathrm{H}$ et al.: Functional magnetic resonance imaging study of writer's cramp. Chin Med J (Engl) 2006; 119: 1263-1271.

Hubsch C, Roze E, Popa T et al.: Defective cerebellar control of cortical plasticity in writer's cramp. Brain 2013; 136: 2050-2062.

Jabusch HC, Vauth H, Altenmüller E: Quantification of focal dystonia in pianists using scale analysis. Mov Disord 2004; 19: 171-180.

Jhunjhunwala K, Kotikalapudi R, Lenka A et al.: Abnormalities of eyehand coordination in patients with writer's cramp: possible role of the cerebellum. Tremor Other Hyperkinet Mov (N Y) 2017; 7: 499.

Lohmann K, Schmidt A, Schillert A et al.: Genome-wide association study in musician's dystonia: a risk variant at the arylsulfatase G locus? Mov Disord 2014; 29: 921-927.

Mantel T, Meindl T, Li Y et al.: Network-specific resting-state connectivity changes in the premotor-parietal axis in writer's cramp. Neuroimage Clin 2017; 17: 137-144.

Moore RD, Gallea C, Horovitz SG et al.: Individuated finger control in focal hand dystonia: an fMRI study. Neuroimage 2012; 61: 823-831.

Nelson AJ, Blake DT, Chen R: Digit-specific aberrations in the primary somatosensory cortex in Writer's cramp. Ann Neurol 2009; 66: 146-154.

Nibbeling E, Schaake S, Tijssen MA et al.: Accumulation of rare variants in the arylsulfatase $\mathrm{G}$ (ARSG) gene in task-specific dystonia. J Neurol 2015; 262: 1340-1343.

Pesenti A, Barbieri S, Priori A: Limb immobilization for occupational dystonia: a possible alternative treatment for selected patients. Adv Neurol 2004; 94: 247-254.

Pirio Richardson S, Altenmüller E, Alter K et al.: Research priorities in limb and task-specific dystonias. Front Neurol 2017; 8: 170.
Pirio Richardson S, Beck S, Bliem B et al.: Abnormal dorsal premotormotor inhibition in writer's cramp. Mov Disord 2014; 29: 797-803.

Preibisch C, Berg D, Hofmann E et al.: Cerebral activation patterns in patients with writer's cramp: a functional magnetic resonance imaging study. J Neurol 2001; 248: 10-17.

Priori A, Pesenti A, Cappellari A et al.: Limb immobilization for the treatment of focal occupational dystonia. Neurology 2001; 57: 405-409.

Quartarone A, Bagnato S, Rizzo V et al.: Abnormal associative plasticity of the human motor cortex in writer's cramp. Brain 2003; 126: 2586-2596.

Rothkirch I, Granert O, Knutzen A et al.: Dynamic causal modeling revealed dysfunctional effective connectivity in both, the corticobasal-ganglia and the cerebello-cortical motor network in writers' cramp. Neuroimage Clin 2018; 18: 149-159.

Rozanski VE, Rehfuess E, Bötzel K et al.: Task-specific dystonia in professional musicians. A systematic review of the importance of intensive playing as a risk factor. Dtsch Arztebl Int 2015; 112: 871-877.

Siebner HR, Rothwell J: Transcranial magnetic stimulation: new insights into representational cortical plasticity. Exp Brain Res 2003; 148: 1-16.

Zeuner KE, Hallett M: Sensory training as treatment for focal hand dystonia: a 1-year follow-up. Mov Disord 2003; 18: 1044-1047.

Zeuner KE, Bara-Jimenez W, Noguchi PS et al.: Sensory training for patients with focal hand dystonia. Ann Neurol 2002; 51: 593-598.

Zeuner KE, Peller M, Knutzen A et al.: Motor re-training does not need to be task specific to improve writer's cramp. Mov Disord 2008; 23: 2319-2327. 